\title{
Solanum nigrum, a new host for powdery mildew disease of Capsicum annuum in the Madurai district of Tamil Nadu, India
}

\author{
A. Sudha ${ }^{\mathrm{A}, \mathrm{B}}$ and P. Lakshmanan ${ }^{\mathrm{A}}$ \\ A Department of Plant Pathology, Tamil Nadu Agricultural University, Coimbatore 641003, India. \\ ${ }^{B}$ Corresponding author. Email: sudhaa1981@yahoo.com
}

\begin{abstract}
In October-November 2004, a severe outbreak of powdery mildew disease incited by Leveillula taurica was observed on Capsicum annuum (cv. K2) (chilli) and caused yield loss up to 80\%. A similar type of symptom was also recorded on Solanum nigrum grown in and around chilli fields. Based on the morphological characteristics and cross infectivity, it has been confirmed that the powdery mildew pathogens from $C$. annuum and $S$. nigrum are the same. The pathogen from $C$. annuum could infect $S$. nigrum and vice versa. Other cultivated plant species were not infected. This might be due to the probable occurrence of physiological races. This is the first report of this organism causing powdery mildew in $S$. nigrum in the Madurai district of Tamil Nadu. The ability of $L$. taurica to infect the native host $S$. nigrum is particularly important because this host plant might serve as an inoculum reservoir for adjacently cultivated $C$. annuum.
\end{abstract}

Powdery mildew incited by Leveillula taurica (anamorph Oidiopsis taurica) is one of the most important diseases of chilli (Capsicum annuum) worldwide and causes yield losses up to $10-15 \%$ (Cerkauskas et al. 1999). During October and November 2004, a severe outbreak of L. taurica was observed in almost all chilli growing areas of Tamil Nadu. About 70-80\% yield reduction was recorded on chilli cv. K2. A similar type of symptom was also observed on the green leafy vegetable $S$. nigrum grown in and around chilli fields. The present study therefore aimed to establish the relationship between these two powdery mildew diseases based on morphological characteristics and host infectivity.

Leaves of $C$. annuum and $S$. nigrum showing typical powdery mildew symptoms were collected separately. Conidia were harvested by dislodging them from infected tissue onto a strip of clear tape, using a camel hair brush. The tapes were mounted on microscopic slides. Slides were stored at $4^{\circ} \mathrm{C}$ after returning them to the laboratory (Correll et al. 1987). Morphological characteristics of the pathogen such as location of mycelia on the host, presence of dimorphic conidia, size and shape of conidia and branching of conidiophores were recorded within $72 \mathrm{~h}$.

Pathogenicity of powdery mildew fungi was tested separately on their respective hosts using the method described by Correll et al. (1987). Tissues showing evidence of infection and sporulation from $C$. annuum and $S$. nigrum were collected separately from the field and incubated at $26 \pm 2{ }^{\circ} \mathrm{C}$ in the laboratory, before use as an inoculum source. In greenhouse tests, seedlings of $C$. annuum and $S$. nigrum used for inoculation and cross inoculation were transplanted separately into earthenware pots (diam. $10 \mathrm{~cm}$ ) containing a garden soil mixture, at the rate of two seedlings per pot. Fifty-day-old seedlings of $C$. annuum and $S$. nigrum were spray-inoculated separately with conidial suspensions $\left(5 \times 10^{5}\right.$ conidia $\left./ \mathrm{mL}\right)$ of the respective powdery mildew fungus after making pinpricks. In another set of experiment, the conidial suspensions were cross inoculated after making pinpricks. For each inoculation about fifteen seedlings were maintained. The relative humidity was maintained between 70 and $80 \%$ RH for a 12 -h period. Symptom development was recorded at weekly intervals.

In greenhouse tests, the infectivity of powdery mildew fungi from $C$. annuum and $S$. nigrum was tested separately on various cultivated plant species, including Allium cepa, Allium sativum, Cajanus cajan, Cicer arietinum, Cyamopsis tetragonoloba, Dolichos laboratory laboratory, Glycine max, Gossypium hirsutum, Hibiscus cannabinus, Lycopersicon esculentum, Phaeseolus vulgaris, Ricinus communis, Solanum melongena and Trigonella foenum graceum. The plants were maintained in earthenware pots $($ diam. $10 \mathrm{~cm})$ at the rate of three seedlings per pot. For each plant species 12 seedlings were maintained. A month after seedlings establishment, $50 \%$ of the plant species were spray-inoculated with powdery mildew fungus from $C$. annuum and the remaining $50 \%$ of plant species were spray-inoculated with powdery mildew fungus from $S$. nigrum. Symptom development was observed at weekly intervals.

Infectivity of chilli powdery mildew (L. taurica) on various economical crops cultivated close to chilli fields was tested by artificial inoculation. Typical powdery mildew symptoms were observed within 7-10 days of inoculation. White powdery growth covered the entire lower surface of leaves within 15 days and corresponding yellow patches on the upper leaf surface were observed. Among the plants tested, only S. nigrum was readily infected by L. taurica within 10 days of inoculation under greenhouse condition. This is the first record of this organism causing powdery mildew on $S$. nigrum in the Madurai district of Tamil Nadu (Fig. 1). Other crops did not show any symptoms even after 30 days.

In the laboratory, the morphological characteristics of the powdery mildew pathogen from $C$. annuum and $S$. nigrum 


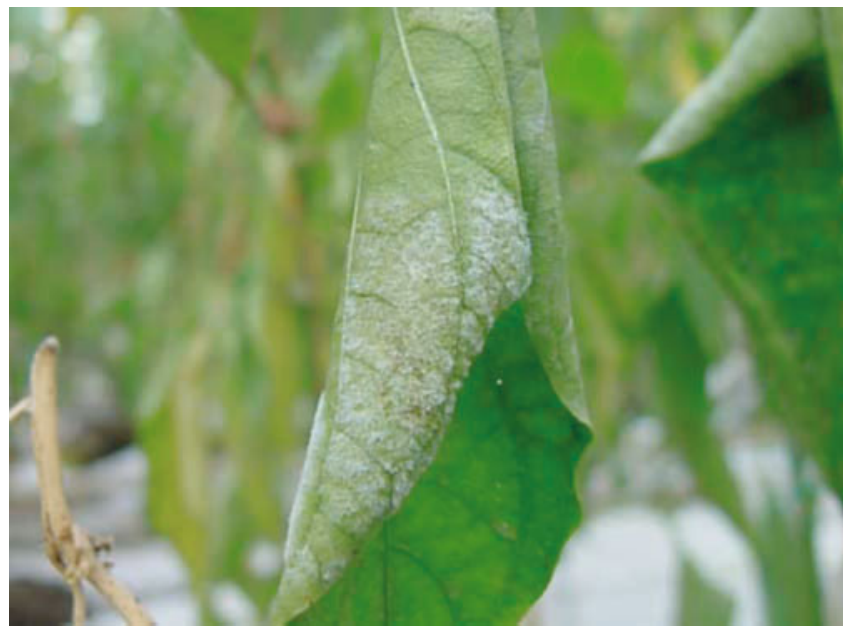

Fig. 1. Powdery mildew of Solanum nigrum caused by Leveillula taurica.

were identical. Mycelium was endophytic, conidia pyriform to obclavate, borne singly on branched conidiophores. Mean conidial measurement were $70.5-48.3 \times 24.5-15.9 \mu \mathrm{m}$. The morphological characteristics of powdery mildew pathogens from C. annuum and S. nigrum were identical and closely resembled those of Oidiopsis taurica, the anamorphic stage of L. taurica, described by Mukerji (1968), Boesewinkel (1980) and Correll et al. (1987).

The relationship between these powdery mildew fungi was further confirmed by cross inoculation. The powdery mildew from C. annuum could infect S. nigrum and vice versa. None of the other plant species tested were infected by these pathogens. The powdery mildew fungus, $L$. taurica, is a unique foliar pathogen in its ability to infect a large and diverse number of plant species. (Hirata 1968; Palti 1974; Correll et al. 1987). Though
L. taurica has a wide host range worldwide, in Tamil Nadu the pathogen from $C$. annuum could infect only $S$. nigrum. This might be due to race or a specialised form of $L$. taurica. A similar observation was also recorded by Correll et al. (1987), where L. taurica from artichoke (Cynara scotynus) could also infect tomato but none of the other plant species tested; Correll et al. (1987) suggested the possible occurrence of physiological races as an explanation for this result. This is the first record of this organism cauing powdery mildew disease on $S$. nigrum in the Madurai district. The ability of $L$. taurica to infect the native host $S$. nigrum is particularly important because this host plant might serve as an inoculum reservoir for adjacently cultivated C. annuum.

\section{References}

Boesewinkel HJ (1980) The morphology of the imperfect states of powdery mildew (Erysiphaceae). Botanical Review 46, 167-224.

Cerkauskas RF, Brown J, Ferguson G, Khosla S (1999) First report of powdery mildew of greenhouse pepper caused by Leveillula taurica in Canada. Plant Disease 83, 781. doi: 10.1094/PDIS.1999.83.8.781A

Correll JC, Gordon TR, Elliott VJ (1987) Host range, specificity and biometrical measurements of Leveillula taurica in California. Plant Disease 71, 248-251. doi: 10.1094/PD-71-0248

Hirata K (1968) Notes on host range and geographical distribution of the powdery mildew fungi. Transactions of the Mycological Society of Japan 9, 73-88.

Mukerji KG (1968) 'Leveillula taurica. CMI Descriptions of pathogenic fungi and bacteria. No. 182.' (Commonwealth Mycological Institute: Kew)

Palti J (1974) Striking divergences in the distribution of Leveillula taurica (Lev.) Arn. on some major crop hosts. Phytopathologia Mediterranea $13,17-22$

Manuscript received 6 March 2007, accepted 21 June 2007 